\title{
FOREWORD
}

\author{
John Walton
}

Mary Hunter Austin (1868-1934) was a woman of her times whose work is especially relevant for our own. Her life and art were rooted in turn-of-the-century events - the capitalist transformation of the western frontier, the marginalization of Native Americans, the struggle for women's rights. At the height of her career in the 1920s she traveled in the society of Herbert Hoover, Margaret Sanger, H. G. Wells, Lincoln Steffens, Martha Graham, and Ansel Adams. Her work was praised by Joseph Conrad, William Butler Yeats, and George Bernard Shaw. Yet this daughter of a Civil War veteran pioneered the modern roles of feminist, environmentalist, advocate for Indian and Hispanic minorities, historical preservationist, bilingual teacher, and organizer of the arts communities in Carmel and Santa Fe. She wrote about these issues with a sharp moral vision that continues to invigorate readers a century later.

Mary Hunter was raised in Carlinville, Illinois, by an austere Methodist mother, Susanna Graham, and Captain George Hunter, a local attorney. Her father's health had been ruined by military service, and he was often confined to his study. Mary was devoted to her father; her committment to a literary career was formed during the days when they read aloud from classics in his wellappointed study. But tragedy entered her life at age ten, 
with the death of her father and younger sister within months of each other - events that nurtured Mary's lifelong spirituality. Susanna carried on with the captain's Civil War pension and a nursing job of her own that put Mary and her older brother Jim through Carlinville's two-year Blackburn College. In 1887 Jim went west, and Susanna decided to follow, moving the family to the outskirts of Bakersfield, California, where they took up homesteads.

Here on the dirt farms of Kern County, with the Tehachapi Mountains rising dramatically from the southern end of the San Joaquin Valley, Mary's writing first flourished. Although she taught school for a time, her preoccupation was riding the countryside, observing the physical environment, and coming to know the sundry Indian, Basque, Chinese, and Mexican peoples of the land. At twenty-four she published her first short stories about these modest folk in the San Francisco-based Overland Monthly.

It was in Kern County, too, in 1891 that she married Stafford Wallace Austin. A refined young man who had graduated from the University of California, an uncommon achievement at the time, her husband was nevertheless a dreamer and dilettante. And Mary, even in her early twenties, was rebellious, and driven - in the parlance of the time, a "woman with views." Their odd marriage might be explained by Mary's desire to escape Jim and Susanna's condescension at home and by the novelty of Wallace's attentions, which must have been flattering to a plain, overserious young woman. In the following year the couple moved to the Owens Valley on the eastern slope of California's Sierra, where Wallace took 
up a series of jobs, notably as Register of the U.S. Land Office, while Mary wrote, taught at the Inyo Academy, struggled with the ill-conceived marriage, and began to raise a daughter, whom they soon realized was retarded.

Mary's Inyo County years mark her formation and emergence as a writer of national prominence. From 1892 to 1906 the Owens Valley was still a frontier community. With characteristic intensity, Mary threw herself into the fine features of this desolate land - the miners' doleful stories, strange itinerant shepherds, the desert landscape and wildlife, a Mexican American village, and the language and life of Indian rancherias where respectable white women did not go. Highly readable nearly a century later, her stories were collected in Land of Little Rain (published in 1903 and still in print), The Basket Woman (1904), and The Flock (1906). Although written in New York during a later phase of her life, The Ford (1917) was fundamentally a reflection on her experience of frontier development in Kern and Inyo - of the social forces at work, the winners and losers, and their character.

Kern County was the locus of ill-gotten land holdings such as the vast Miller-Lux properties, of pitched conflict between leaseholders and the Southern Pacific Railroad that led to the Mussel Slough massacre chronicled by Frank Norris in The Octopus (1901), and of a subsequent oil discovery that converted the agrarian community into a rough-hewn boomtown. Just one hundred miles northeast, but over the trackless Sierra and reached circuitously via Carson City or Mojave, Inyo County's Owens Valley would soon play a key role in Southern California development. For it was the stream- 
laced Eastern Sierra slope and the Owens River that attracted the water seekers. Initially U.S. Reclamation Service planners located a site for an irrigation and power project; agents of metropolitan expansion from Los Angeles followed on their heels. The Owens ValleyLos Angeles controversy, a rural-urban struggle of epic dimensions that began at this time, has persevered throughout the century, resulting in a monumental aqueduct supplying 80 percent of Los Angeles water, legendary grassroots rebellion, precedent-making environmental action, and Southern California urban sprawl as we now know it. In the years leading up to publication of The Ford, Owens Valley citizens protested Teddy Roosevelt's decision to cede the Reclamation Service project to Los Angeles' designs for urban development some $\mathbf{2 4 0}$ miles to the south. Mary Austin lent her talent to the resistance movement, with trenchant critiques in the San Francisco Chronicle, and Wallace joined other public officials in letters and petitions to Washington. Although the local struggle in 1905 failed, it began a tradition of debate and action that would be elaborated in the $1920 \mathrm{~s}$ and $1970 \mathrm{~s}$, until the valley finally obtained a measure of justice.

The Ford is set in fictional Tierra Longa Valley, a composite of Kern and Inyo Counties circa 1905. Oil discovery leads to a stampede of ruthless speculators. Agents from San Francisco (rather than Los Angeles) maneuver behind the scenes to grab land and water rights. The valley's great land baron conspires with "government men" and urban predators in an aqueduct scheme to export the ranchers' water supply. Citizens form a committee to block the powerful urban-landlord alliance but fail to 
see and act on their common economic interests. The specter of power confuses the provincials, and the desultory locals are saved only when the city turns elsewhere for its water. Although the story ends with an uncharacteristic resolution of conflicting interests, the plot boldly draws the frontier dilemma.

The Ford is most animated when it turns to an explanation for this pattern of acquisitive power and yeoman deference. Local farmers and townspeople are weighed down by "their invincible rurality ... . how by as much as they had given themselves to the soil, they were made defenseless in this attack upon it." Captives of the land, they lack a vision for themselves and an alternative to the land baron's master plan. "It isn't the Old Man's capital that the people of the valley are up against, so much as the idea of it, and their idea of the situation, or their lack of ideas.... The greatest common factor of the Tierra Longans was their general inability to rise to the Old Man's stature; they were inferior stuff of the same pattern." They are simultaneously ingenuous and vaguely ambitious. Like Wallace in Mary's own life and the Brent family in The Ford, they hope "to get into something" but have no idea what that something might be. In a lyrical passage she observes, "Capital went about seeking whom it might devour, yet such was their strange illusion about it that they believed that if once they could lay hands on it, Capital could be made to run in their harness, breed in their pastures. To those who owned Capital, and set their brand upon it, it ate out of the hand, but its proper nutriment was the content of poor men's pockets. They railed upon it as wolves that defile the corners of the woodman's hut, and it was the sum of 
all their desire." The words convey to us what Ambrose Bierce called "an unexpected interest [in her] tang of archaism" and a clear moral injunction. Capital is avaricious, and the grave error of common folk is to expect anything but exploitation at the hands of power. Bold action requires ideas, and frontier society generated no compelling alternatives to individualism and commercialism.

Although this evaluation may underestimate grassroots initiative and exculpate urban colonialism, it reveals a fundamental truth neglected in romanticized accounts of the American West but confirmed by historical research. Our pioneer settlers were never oppressed peasants defending communal bonds. Rather, they were precarious entrepreneurs anxious for commercial development. The men, at least, were Progressives in the spirit of Roosevelt's expansive regime. They welcomed federal intervention that promised regional development and later quarreled with Los Angeles mainly over their right to share in the fruits of growth. Women more often understood the self-exploitation underpinning pioneer society. As Mary Austin observed in her autobiography Earth Horizon (1932), "There was a spell of the land over all the men. Men talking together would inevitably express the deeply felt conviction, 'Well, this country is bound to go ahead sometime; just look at it.' Women hearing it would look at one another with sharp - or weary - implications of exasperated resignation." If, by today's standards, she neglected government involvement in frontier society, if urbanization and the state were outside the range of her analytic concerns, she anticipated by many decades our own understanding of 
frontier development and the social class and gender divisions it fostered.

In 1906, when Los Angeles won its first engagement in the Owens Valley water war with the right to build an aqueduct, Mary Austin left her husband and Inyo County for good, committed her daughter to an institution, and began a new life in Carmel's emerging artist community. At thirty-eight she was a recognized, self-supporting writer with broad interests in religion, Native American lore, history, and stage direction at Carmel's Forest Theater. As a professional writer, she soon found it necessary to take up residence in New York, where publishing deals could be more conveniently arranged to provide a regular income. Eventually she settled in Santa Fe, where for the balance of her life she wrote continuously and devoted her time (and her estate) to the local arts community, historical preservation, and the HispanicNative American population.

The Ford stands out among her thirty volumes of short stories, novels, and biography as perhaps her best characterization of American society and a reflection of the formative influences on her writing. It shows her strength, her compassion as far as it went, her impatience, and her determination to get on with the work at hand. And that work helped build a cultural foundation for successful environmental movements of recent years in Inyo and Mono Counties just as it continues to inform feminism, ecology, and Native American studies. Her legacy is a new understanding of the American West and the diverse participants in its creation. 
xvi

FOREWORD

\section{Suggested Reading}

Austin, Mary. 1903. Land of Little Rain. Boston: Houghton Mifflin. Reprint, Albuquerque: University of New Mexico Press, 1974.

-1932. Earth Horizon. Boston: Houghton Mifflin.

- 1987. Western Trails: A Collection of Short Stories by Mary Austin. Selected and Edited by Melody Graulich. Reno: University of Nevada Press.

Fink, Augusta. 1983. I-Mary: A Biography of Mary Austin. Tucson: University of Arizona Press.

Kahrl, William L. 1982. Water and Power: The Conflict over Los Angeles' Water Supply in the Owens Valley. Berkeley: University of California Press.

Stineman, Esther Lanigan. 1989. Mary Austin: Song of a Maverick. New Haven: Yale University Press.

Walton, John. 1992. Western Times and Water Wars: State, Culture, and Rebellion in California. Berkeley: University of California Press. 